\title{
A STUDY OF MODEST FASHION SMES' BUSINESS PERFORMANCE: THE MODERATING ROLE OF BUSINESS MODEL INNOVATION
}

\author{
Aini Edlyn Khurotul ${ }^{\star}$, Nurlaily Ferina, Asmoro Priandhita Sukowidyanti \\ Faculty of Administrative Science, University of Brawijaya, Indonesia \\ *E-mail: edlynaini@gmail.com
}

\begin{abstract}
The significant increase in interest and demand for modest fashion markets provide new opportunities for fashion business people. Nowadays, there are more world's and community's mainstream fashion brands starting to showcase the modest fashion in their collections. Viewing the phenomenon of Indonesian modest fashion development, the government is increasingly and aggressively launching Indonesia as the modest fashion barometer at the Asian level in 2018 and at the world level in 2020. There has not been research examining the modest business process of fashion. So far, the research of modest fashion tends to be related to marketing, culture or religion. The renewal of this research is to associate the modest fashion SMEs having a unique characteristic with the variable opportunity recognition, business model innovation, and business performance. The results of this study present that opportunity recognition has a significant effect on business model innovation and business performance.
\end{abstract}

\section{KEY WORDS}

Recognition, business model innovation, business performance, modest fashion SMEs.

Today, the growth of the modest fashion business is at a very interesting point. Modest fashion is a polite and non-provocative way of dressing to avoid being used as the object of sexual attention (http://www.harpersbazaar.co.id/, 2016). The main characteristic of modest fashion is clothing with pieces that cover most parts of the body, silhouettes or curves, especially for women. Considering the history of fashion development, this fashion style is designed for women and men. The concept of modesty is, to a greater extent, associated with Muslims; in point of fact, this concept is not meant specifically for Muslims. These days, wearing modest clothing is not only meant for an obligation or a spiritual need but has also evolved into a choice of lifestyle.

Nevertheless, the modest fashion growth in recent years has been inevitably influenced by the high demand of Muslim clothing. According to the Global Islamic Economy Report released by Thomson Reuters in collaboration with the Standard Dinar in 2017, Muslim consumers spend around $\$ 243$ billion on clothing in 2015 , with $18 \%$ or about $\$ 44$ billion for modest fashion shopping (GIER, 2017). Muslim consumer spending on clothing is expected to reach $\$ 368$ billion in 2021 or increase by $51 \%$ from 2015 . The emergence of business potential from demographic factors leads fashion businesses to their interest in a modest fashion. Muslim populations around the world are growing twice as fast as non-Muslims, and nearly two-thirds of Muslims are currently under 30 years old (https://www.cbsnews.com, 2017). As millennials, they have the desire to look fashionable.

The rapid increase in interest and demand for modest fashion markets provide new opportunities for fashion business people. Nowadays, there are more world's and community's mainstream fashion brands starting to showcase the modest fashion in their collections. Indonesia, as the world's largest Muslim country, has $13.1 \%$ of the total Muslim population in the world, unquestionably has an influence on modest fashion development. Furthermore, the emergence of Muslim fashion communities, such as the Hijabers (women wearing hijab) Community and Mom Hijabers in various regions in Indonesia, contributes to the development of the modest fashion business in Indonesia as well; these communities often hold bazaars and other fashion events. In 2016, the exports' total value of fashion products was $\$ 16.21$ billion. The modern fashion exports' value reached \$ 4.42 billion; the largest export destination countries were the United States of America, Japan, Germany, Korea and China (HTTP:/www.liputan6.com, 2017). Indonesia has become a large Muslim fashion market share. 
According to Global Islamic Economy Report, Indonesia is the fifth largest Muslim clothing consumption market in the world, with a value of US \$12.69 billion, after Turkey, the United Arab Emirates, Nigeria and Saudi Arabia (GIER, 2017).

Perceiving the phenomenon of Indonesian modest fashion development, the government is increasingly aggressive in making Indonesia as the modest fashion barometer at the Asian level in 2018 and the world level in 2020 (https://halallifestyle.id/, 2017). Indonesia is considered to have the potential of dominating the local and international markets. The government also seeks to encourage the growth of SMEs engaged in a modest fashion. The fashion industry contributed $18.5 \%$ of the total creative economy's Gross Domestic Product and made it the second largest contributor after culinary. Thirty percent of the 750 thousand SMEs in Indonesia are Muslim fashion industries (http://www.kemenperin.go.id/, 2017). With all of its potential, the fashion industry is also expected to contribute more to achieving these targets. From the data, however, Indonesia still undergoes difficulties in developing into the modest direction of world fashion. The country needs its fashion industry sector to be ready from upstream to downstream. Based on the data, the number of modest fashion products consumed in the country is still far greater than the number of exported products. In other words, business people, especially those from modern fashion SMEs, still focus on the local market and have not been oriented to international business. Currently, the largest exporters of Muslim clothing are China, India, and Turkey, which are not the largest Muslim countries. Modest fashion consultant, Franka Soeria, considers that Indonesia's fashion modest SMEs still desperately need access to international networks as well as tutorials that precisely answer the global fashion world's demands, and create quality products.

Therefore, more in-depth studies concerning how modern fashion SMEs can capture opportunity recognition and utilize business model innovation as a scheme or model for solving business problems are needed; the model or scheme is an effort to create sustainable competitive advantages and to improve business performance. There has not been research examining the business process of modest fashion. Up to this time, the researches on modest fashion are more related to marketing, culture or religion (Zohreh et al, 2016; Lewis, 2015; Akou, 2007; Williams and Vashi, 2007; Potts, 2009; Mumin, 2010; Cialdini et al; 1998). The renewal of this research is to associate the modest fashion SMEs having a unique characteristic with the variable opportunity recognition, business model innovation, and business performance.

Opportunity recognition is an essential component of the entrepreneurial process. It is important to note that it is a phenomenon at the individual level. Although there are aspects of its process that might involve entrepreneurial teams or entrepreneurial social networks, especially in the initial stages, it is usually an individual one. Thus, the introduction of opportunities is unique to the creative process. The introduction of entrepreneurial opportunities by individuals is a quite diverse and complex phenomenon (Gartner and Shaver 2004). According to Guo, et al. (2016), business model innovation can mediate between opportunity recognition and business performance; in capturing an opportunity, there is a need to elaborate and give meaning to provide the creation of added value and innovation from the SME business model. The business model is a content, structure, and governance of transactions to create value obtained from business opportunities (Amit and Zott, 2012). Therefore, business model innovation is needed to build a sustainable competitive advantage. Some studies support the existence of a business model innovation related to business performance, as expressed by IBM consultants after interviewing 765 corporate leaders worldwide. As a result, highperformance companies give more than twice the emphasis on business model innovation rather than low-performing companies (IBM Global Business Services, 2006).

To this extent, research involving variable opportunity recognition, business model innovation, and business performance in the context of modern fashion SMEs requires studies from a multidisciplinary perspective. This is presented by MacMillan and Katz (1992) and Mitchell et al. (2002), stating that research on entrepreneurship has a multidisciplinary tradition and bases its theoretical model in a rather eclectic way on the insights of various disciplines, such as economics, sociology, psychology or strategic research (2004). Entrepreneurial behavior cannot be explained only by economic theory, because psychological, cultural and sociological factors are also crucial (Ripsas 1998: 110). The previous research emphasized the 
role of business model innovation as a mediator between opportunity recognition and business performance of SMEs in China. Additionally, there has not been research engaging in modest fashion in developing countries, especially SMEs in Indonesia. Thus, this study intends to view the moderating role of business model innovation in opportunity recognition's effect on business performance engaged in the modest fashion SMEs.

\section{LITERATURE REVIEW}

Opportunity Recognition. This research defines opportunity as an idea that has the potential to be developed into a business. Srarsvathy et al. (2003, in Guo et al., 2016) revealed that there were three opportunities: recognized opportunities, opportunities found, and opportunities created. Among these aspects, opportunity recognition is the most relevant to this research. Gielnik et al. (2012) stated that it is used in creating competitive advantage and great performance. It is interpreted as an individual effort to find and identify opportunities (Ucbasaran et al., 2009).

The scale of SME businesses that are relatively small compared to large companies causes them to be dependent on the opportunities existing in the market in order to survive and to succeed. Previous research showed that SMEs cannot survive and succeed if they do not proactively seek and identify opportunities (Sambasivan et al., 2009). Thus, opportunity recognition has a profound impact on the performance of SMEs (Gielnik et al., 2012). In contrast, Ketchen et al (2007) revealed that the ability of SMEs to gain value and profit from the recognition of opportunities is hindered by the limited resources of SMEs. They are still dependent on external resources in order to recognize the opportunities. Moreover, SMEs are occasionally in a disadvantaged position to obtain these external resources. Thus, the hypothesis in this study is:

$\mathrm{H} 1$ : Opportunity recognition has an effect on business performance.

Business Model Innovation. The definition of business model innovation in this study refers to the research of Schneider and Spieth (2013) which stated that business model innovation is an activity to adopt new ways of doing business. To find the right business model, one must be able to effectively capture opportunities and values through business networks with external stakeholders (Zott and Amit, 2013). Thus, it can be concluded that business model innovation is a new business model based on capitalized opportunities. It also allows companies to offer something different from their competitors because it creates a new business model that produces many new choices in applying as well as exploiting knowledge and technology. The competitive advantages created by business model innovation will improve business performance. This is in line with previous researches finding that business model innovation takes an important part in a business' success (Giesen et al., 2007) and sustainable development (França et al., 2016). Thus, the hypotheses in this study are:

$\mathrm{H} 2$ : Opportunity recognition has an effect on business model innovation;

H3: Business model innovation has an effect on business performance.

The Mediating role of Business Model Innovation. To find out the mediating role of the business model innovation in opportunity recognition's effect on business performance, we identify the relationship of those variables. Business model innovation emphasizes the creation of business models by utilizing existing opportunities. It can be concluded that it is the result of finding opportunities existing in the markets. The recognition of opportunities by SMEs enables them to identify opportunities that can bring profits (Ozgen and Baron, 2007). Moreover, Demil and Lecocq (2010) asserted that it can contribute to the performance of SME businesses in which it utilizes various opportunities' advantages in the market. The results of these studies are in line with a study by Guo et al. (2016) that revealed if SMEs find their business model through existing opportunities, they can improve their business performance. Thus, the hypothesis in this study is:

$\mathrm{H} 4$ : Opportunity recognition has an effect on business performance with business model innovation as a mediating variable. 


\section{METHODS OF RESEARCH}

The population in this study was SMEs from various types of businesses located in Malang; moreover, samples used in this study were 101 SMEs engaged in modest. Malang is a city with eminently rapid creative economic growth. In addition, the number of young entrepreneurs engaged in the modest fashion sector has increased in recent years. This study uses a questionnaire as an instrument for data collection. The variables in this study were measured by a Likert scale with a range of 1 to 5 , in which 1 equals "strongly disagree" and 5 equal to "strongly agree". The dependent variable proposed in this study is business performance. Referring to Lubatkin et al. (2006), SME business performance was measured by 6 items using questions posed to respondents to evaluate business performance compared to its main competitors for 3 years, they are: 1) sales growth rate, 2) market share growth, 3) profit growth, 4) productivity, 5) Return on Assets, and 6) Return on Sales.

Furthermore, the independent variable in this study is opportunity recognition. Opportunity recognition was measured by 4 items adapted from the Chandler and Hanks (1994) and Ozgen and Baron (2007) research, which are: 1) I enjoy thinking about new ways of doing businesses, 2) I frequently identify opportunities to start-up new businesses (even though I may not pursue them), 3) I think of many ideas for new businesses in the past month, and 4) I frequently identify ideas that can be converted into new products or services (even though I may not pursue them).

Meanwhile, the intervening variable in this research is business model innovation. This study measures the innovation of business models with 8 items adapted from the Zott and Amit (2008) research, namely: 1) our business model offers new combinations of products, services, and information, 2) our business model attracts a lot of new suppliers and partners, 3) our business model attracts a lot of new customers, 4) our business model ties participants (customers, suppliers, and partners) in new and innovative ways, 5) we frequently introduce new ideas and innovations into our business model, 6) we frequently introduce new operational processes, routines, and norms into our business model, 7) we are pioneers of the business model, and 8) overall, our business model is novel. This study employs path analysis to determine the effect of opportunity recognition on business performance, with business model innovation as an intervening variable.

\section{RESULTS AND DISCUSSION}

The measurement model of reliability is to meet the standards for the study variables, including all observed variables using the standardized factor loadings, and to calculate the composite reliability for each variable. Reliability test results in table 1 are greater than 0.6 . The recommended value of Fornell \& Larcker (1981) is greater than 0.60. Therefore, all of the variables used in the study are reliable.

Table 1 - Reliability Test Result

\begin{tabular}{|c|c|c|c|}
\hline No & Variable & Cronbach Alpha & Explanation \\
\hline 1 & Opportunity Recognition & 0.616 & Reliable \\
\hline 2 & Business Model Innovation & 0.812 & Reliable \\
\hline 3 & Business Performance & 0.897 & Reliable \\
\hline
\end{tabular}

Based on validity tests result in table 2 , the significant value of each indicator against the significant value of the construct has less than 0.05 . Thus, each attribute or item statement in this research can be considered valid.

The research questionnaire was distributed to the owners of UKM Modest Fashion located in Malang. The respondents were those aware of the company's condition and the three research variables. Based on Table 3, it can be seen that most of the respondents (52\%) had a business age of 1 to 5 years. Only 2 respondents (3\%) had more than 20 years of businesses. Meanwhile, regarding the number of employees, most of the respondents (86\%) had fewer than 10 employees. Only 2 respondents had around 50 to 100 people employees. $67 \%$ of the respondents had less than 250 million IDR as their annual income and only 5 respondents (5\%) had between 1 billion IDR to 5 billion IDR. 
Eurasia: Economics \& Business, 2(20), February 2019

DOI https://doi.org/10.18551/econeurasia.2019-02

Table 2 - Validity Test Result

\begin{tabular}{|c|c|c|c|}
\hline No & Item & Sig. & Explanation \\
\hline 1 & Opportunity Recognition 1 & 0.00 & Valid \\
\hline 2 & Opportunity Recognition 2 & 0.00 & Valid \\
\hline 3 & Opportunity Recognition 3 & 0.00 & Valid \\
\hline 4 & Opportunity Recognition 4 & 0.00 & Valid \\
\hline 5 & Business Model Innovation 1 & 0.00 & Valid \\
\hline 6 & Business Model Innovation 2 & 0.00 & Valid \\
\hline 7 & Business Model Innovation 3 & 0.00 & Valid \\
\hline 8 & Business Model Innovation 4 & 0.00 & Valid \\
\hline 9 & Business Model Innovation 5 & 0.00 & Valid \\
\hline 10 & Business Model Innovation 6 & 0.00 & Valid \\
\hline 11 & Business Model Innovation 7 & 0.00 & Valid \\
\hline 12 & Business Model Innovation 8 & 0.00 & Valid \\
\hline 13 & Business Performance 1 & 0.00 & Valid \\
\hline 14 & Business Performance 2 & 0.00 & Valid \\
\hline 15 & Business Performance 3 & 0.00 & Valid \\
\hline 16 & Business Performance 4 & 0.00 & Valid \\
\hline 17 & Business Performance 5 & 0.00 & Valid \\
\hline 18 & Business Performance 6 & 0.00 & Valid \\
\hline
\end{tabular}

Table 3 - Modest Fashion SMEs Profile

\begin{tabular}{|c|c|c|}
\hline $\mathrm{n} / \mathrm{n}$ & Freq. $(\mathrm{N}=101)$ & $\%$ \\
\hline Business Age & & \\
\hline$<1$ year old & 23 & 22 \\
\hline $1-5$ years old & 53 & 52 \\
\hline $5-10$ years old & 12 & 12 \\
\hline $10-20$ years old & 11 & 11 \\
\hline$>20$ years old & 2 & \\
\hline Number of Employees & & 85 \\
\hline$<10$ people & 86 & 13 \\
\hline $10-50$ people & 13 & 2 \\
\hline $50-100$ people & 2 & 0 \\
\hline$>100$ people & 0 & \\
\hline Income per Year & & 66 \\
\hline$<$ IDR 250 millions & 67 & 23 \\
\hline IDR 250 -500 millions & 23 & 4 \\
\hline IDR 500 millions -1 billions & 4 & 5 \\
\hline IDR 1 - Rp 25 billions & 5 & 0 \\
\hline$>$ IDR 25 billions & 0 & \\
\hline
\end{tabular}

This study applied the Kolmogorov-Smirnov test with a 5\% significance level to detect the presence or absence of normality. Based on the data in Table 4.4 Kolmogorov-Smirnov, it is found that the value is 0.067 and has a significance value $>0.05$, which is 0.200 . This indicates that the data has a normal distribution.

Table 4 - The Result of Normality Test

One-Sample Kolmogorov-Smirnov Test

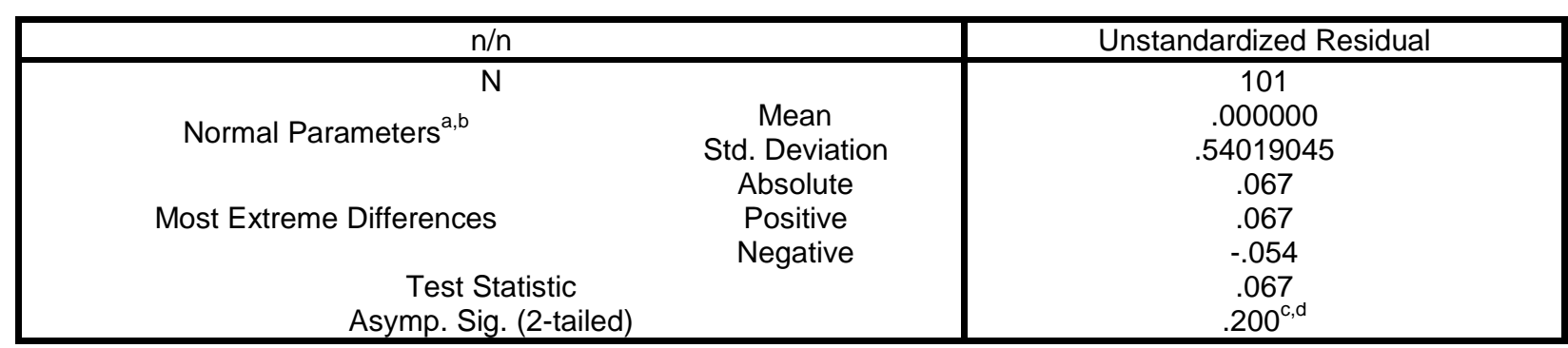

This study worked with the Glejser test to detect the presence or absence of heteroscedasticity. Based on the results of heteroskedasticity test in Table 5, it can be seen that 
the significant result on each variable is worth more than 0.05 ; so, it can be said that there is no heteroscedasticity in the regression model.

Table 5 - the Result of Heteroscedasticity Test Coefficients

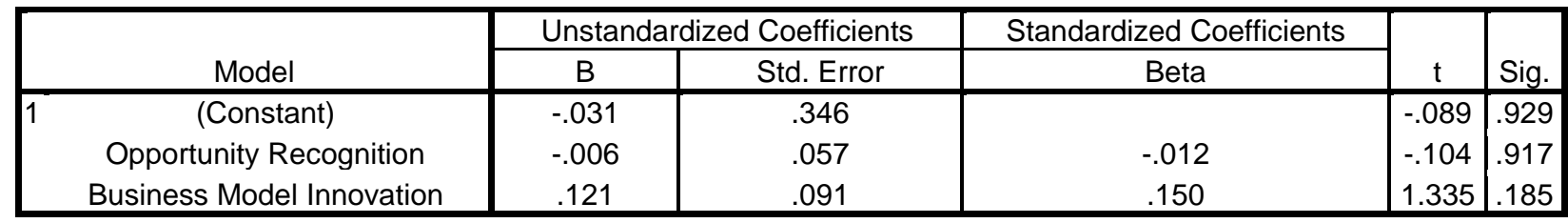

a. Dependent Variable: Abs_ut.

Multicollinearity measurement utilizes the value of Tolerance and Variance Inflation Factor (VIF). Based on Table 6, there is no independent variable that has a value of Tolerance less than 0.1 and no independent variable having VIF value more than 10 . It shows that there is no correlation between the independent variables, which means no multicollinearity.

Table 6 - The Result of Multicollinearity Test

\begin{tabular}{|c|c|c|c|c|c|c|c|}
\hline \multirow{2}{*}{ Model } & \multicolumn{2}{|c|}{ Unstandardized Coefficients } & \multirow{2}{*}{\begin{tabular}{|c|} 
Standardized Coefficients \\
Beta
\end{tabular}} & \multirow[b]{2}{*}{ t } & \multirow[b]{2}{*}{ Sig. } & \multicolumn{2}{|c|}{ Collinearity Statistics } \\
\hline & $B$ & Std. Error & & & & Tolerance & $\mathrm{VIF}$ \\
\hline (Constant) & 1.745 & .623 & & 2.800 & .006 & & \\
\hline Opportunity Recognition & .097 & .103 & .101 & 0.939 & .350 & .795 & 1.258 \\
\hline Business Model Innovation & 394 & .163 & .259 & 2.411 & $\mid 018$ & .795 & 1.258 \\
\hline
\end{tabular}

There are two steps on Path Analysis: the first step is about the test result variable opportunity recognition to business model innovation, which is shown in Path Model I.

Table 7 - Path Model I

\begin{tabular}{|l|l|l|l|l|l|}
\hline \multirow{2}{*}{ Model } & \multicolumn{2}{|l|}{ |lnstandardized Coefficients } & Standardized Coefficients & & Sig. \\
\cline { 2 - 6 } 1 B & Sonstant) & Std. Error & Beta & t \\
Opportunity Recognition & 2.881 & .251 & .453 & 11.459 & .000 \\
\hline
\end{tabular}

a. Dependent Variable: Business Model Innovation.

The second step is describing the effect of business model innovation on the business performance in Path Model II.

Table 8 - Path Model II

\begin{tabular}{|l|l|l|l|l|l|}
\hline \multirow{2}{*}{ Model } & \multicolumn{2}{|l|}{ Unstandardized Coefficients } & Standardized Coefficients & & \\
\cline { 2 - 6 } & $\mathrm{B}$ & Std. Error & Beta & Sig. \\
\hline 1 (Constant) & 1.746 & .623 & & 2.802 & .006 \\
Opportunity Recognition $(\mathrm{X} 1)$ & .097 & .103 & .102 & .946 & .347 \\
Business Model Innovation $(\mathrm{Y})$ & .393 & .163 & .259 & 2.407 & .018 \\
\hline
\end{tabular}

a. Dependent Variable: Business Performance (Z).

Table 8 shows the results of the direct effect analysis of opportunity recognition on business performance as indicated by the Beta value of 0.102 and the significance level of $0.347(p>0.10)$. This demonstrates that there is no significant effect of opportunity recognition variable on business performance; in other words, the first hypothesis $(\mathrm{H} 1)$ is rejected. Table 7 shows the effect of opportunity recognition on business model innovation shown by beta coefficient 0.453 and significant value of 0.000 ( $p<0.05$ ). Thus, the second hypothesis (H2) in this study was accepted. Moreover, the effect of business model innovation on business performance has a Beta value of 0.259 and a significance level of $0.018(p<0.10)$. This shows 
that there is a direct effect of business model innovation on business performance; therefore, the third hypothesis $(\mathrm{H} 3)$ is accepted.

An indirect effect is the influence of the intermediary variable. To find out the effect of opportunity recognition variables on business performance through the business innovation model variable, the researcher multiplied the results of the direct effect on the path traversed.

Indirect Effect $(\mathrm{IE})=(\mathrm{P}(\mathrm{OR}-\mathrm{BMI}))(\mathrm{P}(\mathrm{BMI}-\mathrm{BP}))=0.117$

Based on the result, there is an indirect effect opportunity recognition on business performance through business innovation model. So, the fourth hypothesis $(\mathrm{H} 4)$ is accepted. This indicates that opportunity recognition affects business performance through an innovative business model.

\section{DISCUSSION OF RESULTS}

The effect of opportunity recognition on business performance. According to the previous analysis, it indicates that opportunity recognition has no significant effect on business performance (coefficient $=0.102, t=0.946, p>0.1$ ). The results of this study are not in line with the research conducted by Ozgen and Baron (2007) and Guo et al. (2016) in which opportunity recognition has a significant effect on business performance in the modest fashion of SMEs. This indicates that modest fashion SMEs has lacked on identifying business opportunities to directly improve performance both financially and non-financially because it is still on the ideas level, not implication.

The effect of opportunity recognition on business model innovation. The data analysis found that opportunity recognition has a significant effect on business model innovation (coefficient $=0.453, \mathrm{t}=5.052, \mathrm{p}<0.1$ ). This result is consistent with Guo et al. (2016) presenting that opportunity recognition has a significant direct effect on business model innovation of modest fashion SMEs. It implies that modest fashion SMEs, which identify opportunities and think of new things for their efforts as a form of opportunity recognition, plays a critical role in affecting the business model innovation. Small-medium modest fashion enterprises can increase the business model innovation if they offer a new combination of products, services, information, attracting new customers, incorporating new operations, new routines, and norms by improving new business model, which are more innovative than the competitors.

The effect of business model innovation on business performance. Based on the result analysis, it shows that business model innovation has a significant effect on business performance (coefficient=0.259, $\mathrm{t}=2.407, \mathrm{p}<0.1$ ). This study is in line with Giesen et al. (2007) because the modest fashion SMEs can exploit, create, govern and construct new value to search new market not addressed by their competitors. Thus, it will significantly improve their business performance. In conclusion, business model innovation has a significant effect on business performance on modest fashion SMEs.

The effect of opportunity recognition on business performance through business model innovation. The previous analysis indicates that opportunity recognition has an effect on business performance through business model innovation (coefficient=0.117). This is consistent with the research conducted by Ozgen and Baron (2007) since the modest fashion SMEs have to go through business models innovation to improve their business performance. This is because opportunity recognition has an abstract concept about the information or ideas, so it needs business model innovation to make the form more applicable, also to construct the value and ideas which can increase business performance. It means that opportunity recognition can increase business performance by business model innovation mediation.

\section{CONCLUSION}

This study examines the effect of opportunity recognition on modest fashion SMEs performance mediated by business model innovation. Based on the analysis results, it is concluded that opportunity recognition has a significant effect on business performance through business model performance. On the contrary, opportunity recognition does not have a 
significant direct effect on business performance; so, the role of business model innovation is interpreted as an opportunity which can be applied by SMEs. In further research, it is expected that there will be researches in the modest fashion SMEs at a broader level.

\section{REFERENCES}

1. Akou, H. M. 2007. "Building a New "World Fashion": Islamic Dress in the Twenty-first Century." Fashion Theory, 11(4), 403-422.

2. Amit, R. \& Zott, C. 2001. Value creation in e-business. Strategic Management Journal, 22, 493-520.

3. Amit, R., \& Zott, C. 2012. Creating value through business model innovation. Sloan Management Review, 53: 41-49

4. Cialdini, B.C., Wilhelmina, W., Amy, J.D., Robin, W.D., \& Irena, H. (1998). When Social Role Salience Leads to Social Role Rejection: Modest self Presentation Among Women and Men in Two Cultures. Personality and Social Psychology Bulletin, 24(5), 473-482

5. Creswell, J. W. 2009. Research Design (Qualitative, Quantitative, and Mixed methods approach). Los Angeles: SAGE Publications, Inc.

6. Demil, B. \& Lecocq, X. 2010. Business model evolution: in search of dynamic consistency. Long Range Planning, 43, 227-246.

7. Fornell, C. \& Larcker, D.F. 1981. Evaluating structural equation models with unobservable variables and measurement error. Journal of Marketing Research, 18, 39-50.

8. França, C. L., Broman, G., Robèrt, K. H., Basile, G., \& Trygg, L. (2017). An approach to business model innovation and design for strategic sustainable development. Journal of Cleaner Production, $140,155-166$.

9. Ghozali, I. 2011. Aplikasi Analisis Multivariate Dengan Program SPSS. Semarang: Badan Penerbit Universitas Diponegoro.

10. Gielnik, M.M., Zacher, H., \& Frese, M. 2012. Focus on opportunities as a mediator of the relationship between business owners' age and venture growth. Journal of Business Venturing, 27, 127-142.

11. Giesen, E., Berman, S.J., Bell, R., \& Blitz, A. 2007. Three ways to successfully innovate your business model. Strategy and Leadership, 35, 27-33.

12. Guo, H., Tang, J., Su, Z., \& Katz, J. A. (2017). Opportunity recognition and SME performance: The mediating effect of business model innovation. R\&D Management, 47(3), 431-442. Ketchen, D.J., Ireland, R.D., and Snow, C.C. 2007. Strategic entrepreneurship, collaborative innovation, and wealth creation. Strategic Entrepreneurship Journal, 1, 371385.

13. Lewis, R. (2015). "Uncovering Modesty: Dejabis and Dewigies Expanding the Parameters of the Modest Fashion Blogosphere" Fashion Theory, 19(2), 243-270.

14. Lubatkin, M., Simsek, Z., Ling, Y., and Veiga, J.F. 2006. Ambidexterity and performance on small to medium-sized firms: the pivotal role of TMT behavioral integration. Journal of Management, 32, 646-672.

15. Mumin, N.A. 2010. Research on Online Retailing for Modest Fashion. Unpublished Thesis. Retrieved from https://www.research.manchester.ac.uk/portal/files/54506397/FULL_TEXT.PDF. on January 25, 2019.

16. Ozgen, E. \& Baron, R. 2007. Social sources of information in opportunity recognition: effects of mentors, industry networks, and professional forums. Journal of Business Venturing, 22, 174-192.

17. Potts, J. 2009. Lifting the Veil on Fashion: Filling the Gaps Between Modesty and Fashion Apparels, tesis, https://kb.osu.edu/dspace/handle/1811/44568,

18. Sambasivan, M., Abdul, M., \& Yusop, Y. 2009. Impact of personal qualities and management skills of entrepreneurs on venture performance in Malaysia: opportunity recognition skills as a mediating factor. Technovation, 29, 798-805.

19. Schneider, S. \& Spieth, P. 2013. Business model innovation: towards an integrated future research agenda. International Journal of Innovation Management, 17, 1-34.

20. Sugiyono. 2011. Metode Penelitian Kuantitatif, Kualitatif dan R\&D. Bandung: Afabeta 
21. Ucbasaran, D., Westhead, P., \& Wright, M. 2009. The extent and nature of opportunity identification by repeat entrepreneurs. Journal of Business Venturing, 24, 99-115.

22. Williams, R., \& Vashi, G. 2007. Hijab and American Muslim Women: Creating the Space for Autonomous Selves. Sociology of Religion, 68(3), 269-287.

23. Zohreh, W. Z. \& Ali, M. 2016. The Conceptions Of Modesty And Modest Dress In The Scriptures Of Abrahamic Religions. Afkar, 18(2), 229-270

24. Zott, C. \& Amit, R. 2008. The fit between product market strategy and business model: implications for firm performance. Strategic Management Journal, 29, 1-26.

25. http://www.bbc.com/indonesia/majalah-39510081, Islam akan menjadi 'agama terbesar' pada 2075. Diakses tanggal 27 Mater 2018.

26. http://www.bbc.com/indonesia/majalah-39510081. Accessed on March 26th, 2018.

27. http://www.harpersbazaar.co.id/articles/read/8/2016/2705/Geliat-PerkembanganModestWear di-Indonesia. Accessed on March 27th, 2018.

28. http://www.harpersbazaar.co.id/articles/read/8/2016/2705/Geliat-PerkembanganModestWear di-Indonesia. Accessed on March 26th, 2018

29. http://www.kemenperin.go.id/artikel/4051/Mimpi-Indonesia:-Kiblat-Fashion-Muslim-Dunia. Accessed on March 26th, 2018.

30. http://www.liputan6.com/lifestyle/read/3125325/inspirasi-modest-wear-teranyardalammuffest 2018, Inspirasi Modest Wear Teranyar dalam MUFFEST 2018. Accessed on March 27th, 2018.

31. http://www.republika.co.id/berita/dunia-islam/mozaik/16/10/23/ofi7z3328-busana-muslim diprediksi-jadi-arus-utama-mode. Accessed on March 26th, 2018.

32. https://halallifestyle.id/fashion-beauty/indonesia-kejar-target-jadi-kiblat-fashion-muslim, Indonesia Kejar Target jadi Kiblat Fashion Muslim. Accessed on March 27th, 2018.

33. https://www.cbsnews.com/news/why-the-apparel-industry-is-embracing-muslimfashion/,Why the apparel industry is embracing Muslim fashion. Accessed on March 27th, 2018. 